Faculty of Human and Social Development

Faculty Publications

Climate Change, An Unwelcome Legacy: The Need to Support Children's Rights to Participate in Global Conversations

Ziba Vaghri

2018

This article was originally published at:

https://www.jstor.org/stable/10.7721/chilyoutenvi.28.1.0104

Citation for this paper:

Vaghri, Z. (2018). Climate Change, An Unwelcome Legacy: The Need to Support Children's Rights to Participate in Global Conversations. Children, Youth and Environments, 28(1), 104-114.

http://www.jstor.org/stable/10.7721/chilyoutenvi.28.1.0104 


\title{
Climate Change, An Unwelcome Legacy: The Need to Support Children's Rights to Participate in Global Conversations
}

\author{
Ziba Vaghri \\ Faculty of Human and Social Development \\ University of Victoria
}

\begin{abstract}
Citation: Vaghri, Z. (2018). Climate change, an unwelcome legacy: The need to support children's rights to participate in global conversations. Children, Youth and Environments, 28(1), 104-114. Retrieved from

http://www.jstor.org/action/showPublication?journalCode=chilyoutenvi
\end{abstract}

\begin{abstract}
The UN Convention on the Rights of the Child (CRC) articulates children's rights to be heard and to participate in decisions that affect them. In spite of widespread ratification of the $C R C$, and the recognition of youth as a major stakeholder group with the right to participate in conversations related to climate change, children have not been adequately included in climate change decision-making at a global level, and attempts to facilitate their participation have rarely been more than tokenistic. This paper looks at this issue and pleads for better inclusion of children in conversations and decision-making on climate change.
\end{abstract}

Keywords: climate change, Convention on the Rights of the Child, climate justice, child participation, child rights 
The General Assembly of the United Nations (UN) adopted the Convention on the Rights of the Child (CRC) in 1989. It has now been ratified by 196 countries, making it the most highly ratified human rights treaty in history. ${ }^{1}$ The CRC recognizes specific rights for every child under the age of 18, through 54 articles and a set of optional protocols. Because the CRC acknowledges that rights have a significant impact on children's health and development, it lays out the rights to participate and to be heard as core principles of the treaty (United Nations General Assembly, 1989). Despite ratification of the CRC by almost every member of the UN, many children are finding it difficult to exercise these rights. We, as adults charged with upholding the CRC, are failing to provide environments for our children and youth that enable them to fulfill their rights, including the rights to be heard and to participate in decision-making on issues that affect their lives (CRC Article 12; United Nations General Assembly, 1989). Of all the issues that affect the lives and futures of children, perhaps the most pressing is climate change.

We are now living in what some describe as the Anthropocene epoch, a period of time that began with mass industrialization, during which human activity has disrupted Earth's natural systems (Whitmee et al., 2015). We have arrived at a point where life on Earth is threatened in quality, quantity, and diversity as a result of the disturbances in ecological determinants of health, such as water, air, natural resources, climate, and contaminants (Hancock, Spady, \& Soskolne, 2015). Exploitation of natural resources and an increase in greenhouse gas emissions leading to global warming has resulted in habitat loss and major disruptions to the food cycles of many species, contributing to a sharp rise in the rate of species extinctions worldwide (Center for Biological Diversity, n.d.). Since species do not exist in isolation, every extinction has ripple effects, and some extinctions have already had immediate negative impacts for human life, such as a decline in crops due to the loss of pollinators (Food and Agriculture Organization of the United Nations, 2008). The Lancet Commission on Planetary Health points out that this is an issue that spans generations:

We have been mortgaging the health of future generations to realise economic and development gains in the present. By unsustainably exploiting nature's resources, human civilisation has flourished but now risks substantial health effects from the degradation of nature's life support systems in the future (Whitmee et al., 2015, p. 1973).

Through short-sighted mismanagement of our planet's resources, past and current generations have set in motion a process that will continue to unfold long after those of us alive today are gone.

There are a few concepts that are integral to understanding how climate change affects the rights of children. Climate justice is an approach to climate action that links human rights with development in order to safeguard the rights of the most vulnerable (Mary Robinson Foundation, 2015). The climate justice approach encompasses dimensions of both place and time, utilizing the concepts of

\footnotetext{
${ }^{1}$ All UN member states except the United States of America have ratified the CRC.
} 
intergenerational equity and international equity. Intergenerational equity (fairness between generations) is the idea that we have inherited the earth from previous generations, and we are obligated to pass it on in good condition to future generations (Mary Robinson Foundation, 2015; Weiss, 1990). International equity (fairness between nations), in the context of climate change, acknowledges that countries differ in their contributions to climate change, their vulnerability to the effects of climate change, and in their ability to mitigate the causes of climate change; therefore, the international burden of reducing climate change risk should be distributed fairly (Cazorla \& Toman, 2000). The world population is undergoing a sharp demographic shift. It is estimated that by 2025, the world's least-developed countries will contain almost one-quarter of the worldwide population of children under the age of five (United Nations, 2010). Although these countries have generally contributed less to climate change than more developed countries, due to their limited resources and a lack of mechanisms to cope with devastating climatic events such as drought and rising sea levels, they are likely to bear the brunt of the effects of climate change (United Nations Framework Convention on Climate Change, 2007). Furthermore, it is the youngest citizens of these countries that will be the most affected (Commission on Social Determinants of Health, 2008). Our treatment of the planet has created a life-threatening situation in which generations to come will suffer more than the present population, and children in the world's least developed countries will suffer most of all.

Childhood is a vulnerable stage of human development, placing children at a higher risk of negative impacts from climate change in a number of ways. Malnutrition is already one of the greatest contributors to the mortality of children under the age of five worldwide (UNICEF, n.d.), and climate change is likely to increase food shortages resulting from amplified natural events such as heat, cold, drought, rain, and flooding (Whitmee et al., 2015). Since children tend to be curious and often play outdoors, they are at a higher risk of being exposed to environmental health hazards, such as radiation or accumulated contaminants. Due to the relative fragility of children's bodies, they are generally at a disadvantage when faced with floods, storms, and other severe weather conditions, and endure the heaviest losses from natural disasters (Gibbons, 2014; Martin, 2010). Climate change is contributing to a sharp increase in the number of children affected by natural disasters, estimated to reach up to 175 million per year by the year 2020; the vast majority of these children live in developing countries (Martin, 2010). Young children are also especially susceptible to acute respiratory infections, diarrhea, malaria, and other vector-borne diseases, which are leading causes of death for children under the age of five worldwide (UNICEF, 2009). These diseases are highly sensitive to climatic conditions and are likely to become more widespread, moving into higher altitudes and latitudes, as the planet warms (UNICEF, 2009). In addition to negatively impacting the natural environment, climate change is expected to contribute to civil unrest as it intersects with the social, economic, and political realities of nations (Smith \& Vivekananda, 2007). For children, this means an increased risk of injury or death in violent conflicts, and the threat of recruitment into armed forces and/or forced displacement and migration, which may result in separation from their families and psychological, emotional, and social trauma. 
Lastly, children who are displaced and without adult protection become easy targets for exploitation, sexual abuse, and trafficking (Maala M'jid, 2013).

The children of today and tomorrow will be the most affected by climate change, though they bear no responsibility for causing it; yet, world leaders are not adequately allowing them to represent themselves and future generations when considering solutions to the problems created by climate change. Denying children their rights to participate in decisions that affect their future has the potential to further compound their suffering. Children who have already been born have a right to be included in climate change conversations so that they can advocate for themselves; it may be argued that they are also in the best position to represent and advocate for future generations. Those yet to come will be greatly affected by climate change and need to be included in our thinking about solutions. The existence of climate change already threatens the right to life and survival (CRC Article 6) delineated by the CRC; the manner in which global authorities are responding to climate change is further violating rights such as children's rights to express their opinions (Article 13), to be heard, and to participate (Article 12), among many others.

Global leaders, for the most part, recognize the need for swift action concerning climate change. This action needs to be taken collectively and involve everyone who is and will be affected by the situation. The UN Office of the High Commissioner for Human Rights has demanded climate justice, declaring:

Climate justice requires that climate action is consistent with existing human rights agreements, obligations, standards and principles. Those [children] who have contributed the least to climate change unjustly and disproportionately suffer its harms. They must be meaningful participants in and primary beneficiaries of climate action (Office of the High Commissioner for Human Rights, 2015, p. 2).

Despite this declaration, children's participation in attempts to mitigate climate change continues to face many challenges. Children are often the forgotten parties in global discussions and agreements on climate change. In 1992, the UN held the first Conference on Environment and Development, also known as the Rio Summit or Earth Summit. Among the legally binding agreements resulting from this summit was the United Nations Framework Convention on Climate Change (UNFCCC), which was opened for the signature of UN member states. Though the UNFCCC calls for preserving the global climate for present and future generations, it contains no mention of children. Furthermore, the UNFCCC Guidelines for National Communications (the document which guides reporting on implementation of the terms of the UNFCCC by its signatories) contains no reference to reporting on developments that disproportionately affect children. This is just one example of the ways in which children are excluded from climate change conversations at a global level. When efforts have been made to include children in global conversations on climate change, the efforts are often tokenistic and inadequately supported. In 2008, the UN Joint Framework Initiative on Children, Youth and Climate Change was developed as a joint effort between the secretariat of the 
UNFCCC and various youth organizations. Despite the fact that one of the central reasons for establishing this entity was to empower children and youth to take action on climate change, young people have consistently failed to influence the Conference of Parties (COP) ${ }^{2}$, which is the conference of the governing body of the UNFCCC. At the COP 19 held in Warsaw in 2013, youth delegates organized three side events to highlight children's vulnerability and to draw attention to their agency in effectively adapting to climate change, but none of these efforts or the core ideas communicated in them were reflected in the final declarations of the conference. ${ }^{3}$ Unfortunately, this trend has continued at every subsequent COP, with final agreements and declarations failing to mention children, youth, or the next generation.

Major barriers to child participation in government decision making include a lack of funding and staffing for child participation programs (Davey, Lea, Shaw, \& Burke, 2010). In decisions related to climate change, this lack of participatory set-up stems from a lack of recognition of children as stakeholders who are able to contribute anything valuable. Conceptions of who children are and of what they are capable are influenced by culture, history, and politics, leading to differing views on the value of children's participation in decision making (Kirchschlaeger, 2012). However, the CRC frames children as individual self-agents with independent minds and ideas; they are subjects, not objects, of rights (Kirchschlaeger, 2012). In light of this, the fact that children's voices remain absent from the formal outcomes of global climate conversations, despite their physical presence at these gatherings, warrants a great deal of concern. The Lundy Model of child engagement and participation stipulates that, in order to fully implement Article 12 of the CRC, four conditions must be met (Lundy, 2007):

- Space: children must be given the opportunity to express a view

- Voice: children must be facilitated to express their views

- Audience: the view must be listened to

- Influence: the view must be acted upon, as appropriate

Tokenistic inclusion of a few youth in adult-dominated forums does not qualify as proper child participation and certainly does not allow world leaders to tap into the amazing powerhouse of insight and creativity that young people hold. UNICEF field research conducted in five East Asian and Pacific Island countries suggests that youth have the ability to be strong advocates and play central roles in helping their families, schools and communities adapt to climate change, and find solutions for different aspects of climate change (Lawler \& Patel, 2012). When children and youth are given real opportunities to participate, they are empowered; they gain social and personal competencies while exercising their inherent rights and fulfilling their civic responsibilities (Checkoway, 2011). Involving young people in global climate change discussions has the potential to create an engaged, well-informed

\footnotetext{
2The Conference of Parties is comprised of all states parties that have ratified the UNFCCC. ${ }^{3}$ See Youth Portal COP 19 for discussion of the UN Joint Framework Initiative on Children, Youth and Climate Change, and various activities of UN agencies. Available at http://unfccc.int/cc_inet/cc_inet/youth_portal/items/6519.php
} 
youth population that is more resilient to the socioeconomic and psychological impacts of climate change (Lawler \& Patel, 2012). The CRC, international frameworks on climate change, and the UN's Sustainable Development Goals all support child and youth participation and education as part of the global response to climate change. Agenda 21, a UN sustainable development action plan, ${ }^{4}$ identifies young people as a major stakeholder group with the right to participate in sustainable development (United Nations Division for Sustainable Development, 1992). Including children recognizes that allowing them to participate has multilateral benefits: not only does it promote children's social, emotional, and cognitive development and encourage them to actively engage in civic life, but it also allows the global community to benefit from the abundance of insight, creativity, and enthusiasm that children have to contribute to discussions on climate change.

In efforts to include young people in meaningful ways in conversations about climate change, it is important that their participation be a sustainable part of ongoing government processes and in every aspect of government functioning, with the views of children given due weight in accordance with their age and maturity (Caballero, 2012; Kirchschlaeger, 2012; Ponet, Jabre, Hanmer, \& Karkara, 2011). A successful example of this model can be found in children's parliaments and youth councils, which have been gaining attention in recent years. These forums can provide good opportunities for children to exercise their rights to participation under the CRC, but only if there are follow-up mechanisms in place to implement the outcomes of the consultations with children, clear channels for the decisions of child parliaments and councils to influence the proceedings of parliamentary bodies, and feedback to inform the children of the impact of their participation (Lundy, 2007; Ponet et al., 2011). In countries where child parliaments are allowed to interact with the national parliament, and the views and opinions of child parliamentarians are respected, children can have a real impact on decisions made by their governments. For example, in Bolivia, members of the National Congress of Children and Young People developed 147 law proposals between 2010 and 2013, 72 of which were adopted by the Bolivian Congress (World Vision, 2015). Child participation can have a significant impact on local levels as well. In the Municipality of San Francisco in the Philippines, when children were allowed to vote in a community-wide referendum on whether to relocate schools in areas vulnerable to landslides, they were able to overcome opposition to relocation from parents and other adult community members and work with provincial authorities to move their schools to safer locations (Stone, 2012).

The key to achieving the goal of recognizing the rights of children as stakeholders in climate change decisions lies in investment in integrated child-centered approaches to educating children about climate change and human rights (Goodmann, 2012; Kirchschlaeger, 2012). Education, a right in itself (CRC Articles 28 and 29), is also the foundation of children's ability to participate in climate

\footnotetext{
${ }^{4}$ Agenda 21 is a product of the 1992 UN Conference on Environment and Development. It is an action agenda for the UN as well as for other multilateral organizations and national and local governments.
} 
change conversations and to claim their own rights (Kirchschlaeger, 2012). Additionally, well-educated children are better equipped to recognize threats, more capable of adapting to changing climate conditions, and more effective communicators to their families and wider communities (Caballero, 2012; Stone, 2012). For example, education was the main reason that, during the 2011 Fukushima earthquake and tsunami, many Japanese children played key roles in moving their peers out of harm's way (Stone, 2012).

Climate change is already negatively impacting the lives of children and youth of today, and will certainly continue to do so for generations to come, if it is not tackled in an inclusive manner. By taking action today we may be able to mitigate some of the challenges to human life that the future holds. In these inclusive actions, we must listen to and act upon the voices, ideas, and opinions of all affected parties, including children and youth. Young people have the right to be heard, and this right should be upheld when decisions are made about how to address climate change. Now, more than ever, we need to advocate for these rights so we can collaboratively advance intergenerational climate justice. Let us listen to the voice of our children and youth who need our support to exercise their rights. Let us act upon on their visions and plans, as reflected in a summary of comments and letters from young people all over the world at UNICEF-sponsored conferences:

We would like to move forward with a multigenerational, multidisciplinary vision: Working together, leaders and youth can redesign how society operates. Together we can lobby for a holistic education and climate-change curriculum so that today's youth are not only climate-change literate but are equipped with the tools to act. We are willing to make a difference (UNICEF, 2007, p. 3).

The exclusion and/or merely tokenistic inclusion of children in global conversations on climate change undermines the global community's accountability to children and the legally binding obligations under the CRC and rule of law. The CRC, with its unprecedented ratification rate, holds a great deal of political will and power. We must leverage this power to advance intergenerational climate justice (Gibbons, 2014).

\section{Acknowledgement}

The author would like to acknowledge funding from the Canadian Institutes of Health Research (CIHR) and the Michael Smith Foundation for Health Research (MSFHR) that facilitated the development of this manuscript. The author would also like to acknowledge Dr. Trevor Hancock for reviewing and providing some guidance for the manuscript. Lastly, my appreciation is extended to Ms. Homa Movahedi and Julia Nelson for their kind assistance with the literature search and editing.

Dr. Ziba Vaghri is an Assistant Professor and the Director of the CIHR-funded GlobalChild Program in the School of Public Health and Social Policy at the University of Victoria in Victoria, British Columbia. Her work focuses on creating linkages between children's development and their rights as articulated by the CRC. 
She has led the global initiatives ECRI and GlobalChild, conducted under the auspices of the UNCRC Committee.

\section{References}

Caballero, S. S. (2012). Climate change and its impact on children. In J. Zermatten, P. R. Gapany, A. C. Messer, E. Monnay, P. Roduit, A. Prince, ... D. Volonakis (Eds.), Changement climatique: impacts sur les enfants et leur droits Climate change: impact on children and on their rights (pp. 39-57). Sion, Switzerland: Institut international des Droits de l'Enfant (IDE). Retrieved from http://www.childsrights.org/documents/publications/livres/Book_actesIDE2011 _chgmts_climatiques.pdf

Cazorla, M., \& Toman, M. (2000). International equity and climate change policy, 202-328. Retrieved from http://www.rff.org

Center for Biological Diversity (n.d.). The extinction crisis. Retrieved December 20, 2017, from

http://www.biologicaldiversity.org/programs/biodiversity/elements_of_biodiver sity/extinction_crisis/

Checkoway, B. (2011). What is youth participation? Children and Youth Services Review, 33(2), 340-345. https://doi.org/10.1016/J.CHILDYOUTH.2010.09.017

Commission on Social Determinants of Health (2008). Closing the gap in a generation: Health equity through action on the social determinants of health. Geneva. Retrieved from http://apps.who.int/iris/bitstream/10665/43943/1/9789241563703_eng.pdf

Davey, C., Lea, J., Shaw, C., \& Burke, T. (2010). Children's participation in decision-making: Survey of participation workers. Retrieved from https://www.childrenscommissioner.gov.uk/wpcontent/uploads/2017/07/Childrens_participation_in_decision-making__survey_of_participation_workers.pdf

Food and Agriculture Organization of the United Nations (2008). Climate change and biodiversity for food and agriculture. In High level conference on food security: The challenge of climate change and bioenergy. Rome. Retrieved from http://www.fao.org/uploads/media/FAO_2008a_climate_change_and_biodivers ity_02.pdf

Gibbons, E. D. (2014). Climate change, children's rights, and the pursuit of intergenerational climate justice. Source: Health and Human Rights, 16(1), 1931. Retrieved from http://www.jstor.org/stable/healhumarigh.16.1.19

Goodmann, D. (2012). UNFCCC and child rights: An intergenerational veiw of global environmental policy. In J. Zermatten, P. R. Gapany, A. C. Messer, E. Monnay, 
P. Roduit, A. Prince, ... D. Volonakis (Eds.), Changement climatique: Impacts sur les enfants et leur droits Climate Change: Impacts on children and on their Rights (pp. 18-38). Sion, Switzerland: Institut international des Droits de I'Enfant (IDE).

Hancock, T., Spady, D. W., \& Soskolne, C. L. (Eds.) (2015). Global change and public health: Addressing the ecological determinants of health. Canadian Public Health Association. Retrieved from

https://www.researchgate.net/publication/277666386_Global_Change_and_Pu blic_Health_Addressing_the_Ecological_Determinants_of_Health_The_Report_i n_Brief_Working_Group_on_the_Ecological_Determinants_of_Health

Kirchschlaeger, P. G. (2012). Evolution of the international environment law and position of child from a philosophical perspective. In J. Zermatten, P. R. Gapany, A. C. Messer, E. Monnay, P. Roduit, A. Prince, ... D. Volonakis (Eds.), Changement climatique: impacts sur les enfants et leur droits Climate change: impact on children and on their rights (pp. 75-92). Sion, Switzerland: Institut international des Droits de l'Enfant (IDE). Retrieved from

http://www.childsrights.org/documents/publications/livres/Book_actesIDE2011 _chgmts_climatiques.pdf

Lawler, J., \& Patel, M. (2012). Exploring children's vulnerability to climate change and their role in advancing climate change adaptation in East Asia and the Pacific. Environmental Development, 3, 123-136.

https://doi.org/10.1016/J.ENVDEV.2012.04.001

Lundy, L. (2007). "Voice" is not enough: Conceptualising Article 12 of the United Nations Convention on the Rights of the Child. British Educational Research Journal, 33(6), 927-942. https://doi.org/10.1080/01411920701657033

Maala M'jid, N. (2013). Report of the Special Rapporteur on the sale of children, child prostitution and child pornography.

Martin, M.-L. (2010). Child participation in disaster risk reduction: The case of flood-affected children in Bangladesh. Third World Quarterly, 31(8), 13571375. https://doi.org/10.1080/01436597.2010.541086

Mary Robinson Foundation (2015). Meeting the needs of future generations: Applying the principle of intergenerational equity to the 2015 processes on climate change and sustainable development. Retrieved from https://www.mrfcj.org/wpcontent/uploads/2015/09/MRFCJPositionPaper_MeetingtheNeedsofFutureGener ations_12August2015.pdf

Office of the High Commissioner for Human Rights (2015). Understanding human rights and climate change: Submission of the Office of the High Commissioner for Human Rights to the 21st Conference of the Parties to the United Nations Framework Convention on Climate Change. Retrieved from 
http://doi.wiley.com/10.1080/01411920701657033

Ponet, D., Jabre, K., Hanmer, S., \& Karkara, R. (2011). A handbook on child participation in parliament. Retrieved from

https://www.ipu.org/file/1092/download?token=4RQIJfmq\%0A

Smith, D., \& Vivekananda, J. (2007). A climate of conflict. Retrieved from https://www.preventionweb.net/files/7948_AClimateOfConflict1.pdf

Stone, L. (2012). Sustainable development and the democratic participation of the child. In J. Zermatten, P. R. Gapany, A. C. Messer, E. Monnay, P. Roduit, A. Prince, ... D. Volonakis (Eds.), Changement climatique: impacts sur les enfants et leur droits Climate change: impact on children and on their rights (pp. 149153). Sion, Switzerland: Institut international des Droits de l'Enfant (IDE). Retrieved from http://www.childsrights.org/documents/publications/livres/Book_actesIDE2011 _chgmts_climatiques.pdf

UNICEF (n.d.). Infant and under-five mortality. Retrieved from https://www.unicef.org/specialsession/about/sgreport-pdf/01_InfantAndUnderFiveMortality_D7341Insert_English.pdf

UNICEF (2007). Climate change and children. Retrieved from https://www.unicef.org/publications/files/Climate_Change_and_Children.pdf

UNICEF (2009). The state of the world's children: Celebrating 20 years of the Convention on the Rights of the Child. Retrieved from www. unicef.org

United Nations (2010). Accelerating achievement of the MDGs by lowering fertility: Overcoming the challenges of high population growth in the least developed countries. Retrieved from

http://www.un.org/en/development/desa/population/publications/pdf/popfacts/ popfacts_2010-5.pdf

United Nations Division for Sustainable Development (1992). Agenda 21. In United Nations Conference on Environment and Development. Rio de Janeiro.

Retrieved from https://sustainabledevelopment.un.org/content/documents/Agenda21.pdf

United Nations Framework Convention on Climate Change (2007). Climate change: Impacts, vulnerabilities and adaptation in developing countries. Retrieved from https://unfccc.int/resource/docs/publications/impacts.pdf

United Nations General Assembly (1989). Convention on the Rights of the Child. Treaty Series, 1577. Retrieved from http://www.ohchr.org/Documents/ProfessionalInterest/crc.pdf 
Weiss, E. B. (1990). Our rights and obligations to future generations for the environment. The American Journal of International Law, 84(1), 198-207. Retrieved from http://www.jstor.org/stable/2203020

Whitmee, S., Haines, A., Beyrer, C., Boltz, F., Capon, A. G., Ferreira de Souza Dias, B., ... Yach, D. (2015). Safeguarding human health in the Anthropocene epoch: Report of The Rockefeller Foundation-Lancet Commission on planetary health. www. thelancet.com (Vol. 386). https://doi.org/10.1016/S01406736(15)60901-1

World Vision (2015). Children's parliaments and children's councils in World Vision programmes. Retrieved from http://www.wvi.org/sites/default/files/Children's Parliaments and Children's Councils in WV programmes.pdf 